\title{
Oxalate Coprecipitation of Doped Ceria Powder for Tape Casting
}

\author{
Jan Van Herle, ${ }^{*}$ Teruhisa Horita, Tatsuya Kawada, Natsuko Sakai, Harumi Yokokawa \\ \& Masayuki Dokiya
}

National Institute for Materials and Chemical Research, 1-1 Higashi, Tsukuba Science City, Ibaraki 305, Japan

(Received 27 August 1996; accepted 8 October 1996)

\begin{abstract}
Twenty cation per cent yttria doped ceria $\mathrm{Ce}_{0.8} \mathrm{Y}_{0.2} \mathrm{O}_{1.9}$ was prepared by an optimised oxalate coprecipitation route to give fine sinterable powder. This was formulated into slurries for tape casting of the doped ceria solid electrolyte used in solid oxide fuel cells. Prior dry milling of the powder was found to be most effective to further reduce the average agglomerate size, which allowed to sinter dense membranes at $1400^{\circ} \mathrm{C}$ for $2 \mathrm{~h}$, among the best results obtained so far for tape cast doped ceria. Ball milling of the powder, composition and viscosity of the slurry as well as sintering conditions of different tapes are discussed. (C) 1998 Elsevier Science Limited and Techna S.r.l.
\end{abstract}

\section{INTRODUCTION}

The majority of current solid oxide fuel cell (SOFC) systems are based on $\approx 200 \mu \mathrm{m}$ thick self supporting yttria-stabilized zirconia (YSZ), an impervious oxide ion solid electrolyte of intermediate conductivity that requires high operating temperatures of $\geq 900^{\circ} \mathrm{C}$. This condition increases materials and systems costs and accelerates cell stack degradation. A tendency has grown over the last two years to lower this temperature to around $700^{\circ} \mathrm{C}$ by either (i) reducing the YSZ electrolyte thickness to a non-supporting structure or (ii) by replacing the YSZ by other oxide ion electrolyte materials of superior conductivity, in order to reduce the internal cell resistance along with the operating temperature. Doped ceria constitutes the most serious candidate alternative at the moment. A major concern is the lack of availability of fine doped ceria powder, sinterable at normal to low temperatures $\left(\leq 1400^{\circ} \mathrm{C}\right)$, in particular for tape casting application. Tape casting constitutes an attractive, cheap, industrial approach to the large scale fabrication of ceramic sheets, that has long

\footnotetext{
*To whom correspondence should be addressed.

tCurrent address: Ecole Polytechnique de Lausanne, Department of Chemistry, Laboratory of Photonics and Interfaces, 1015 Lausanne, Switzerland.
}

been fully established for the standard YSZ electrolyte, but not yet for the promising ceria-based electrolytes for SOFC.

Most reports on doped ceria involve thick compacts, fired at unusual high temperature (1600$1700^{\circ} \mathrm{C}$ ) to achieve reasonable densities. Lower firing temperature allows (i) energy saving, (ii) the use of standard ovens without expensive heating elements, (iii) better mechanical properties of the finer grained sintered material and (iv) cofiring with other components of the cell.

In a previous report, ${ }^{1}$ some important parameters regarding the powder preparation by oxalate coprecipitation were already identified. The 'as-calcined' powder could be pressed and fired to high density compacts at low temperature, but not tape cast, because a crucial milling step was lacking. In this report, other parameters for yielding the fine sinterable doped ceria powder are described in detail, with particular attention for the tape casting application.

\section{EXPERIMENTAL}

An overview of the steps involved in the powder preparation of yttria-doped ceria (YDC) by the oxalate coprecipitation route is sketched in the flow chart of Fig. 1. Metal ion solutions of precise 
$\underline{\text { Coprecipitation procedure }}$

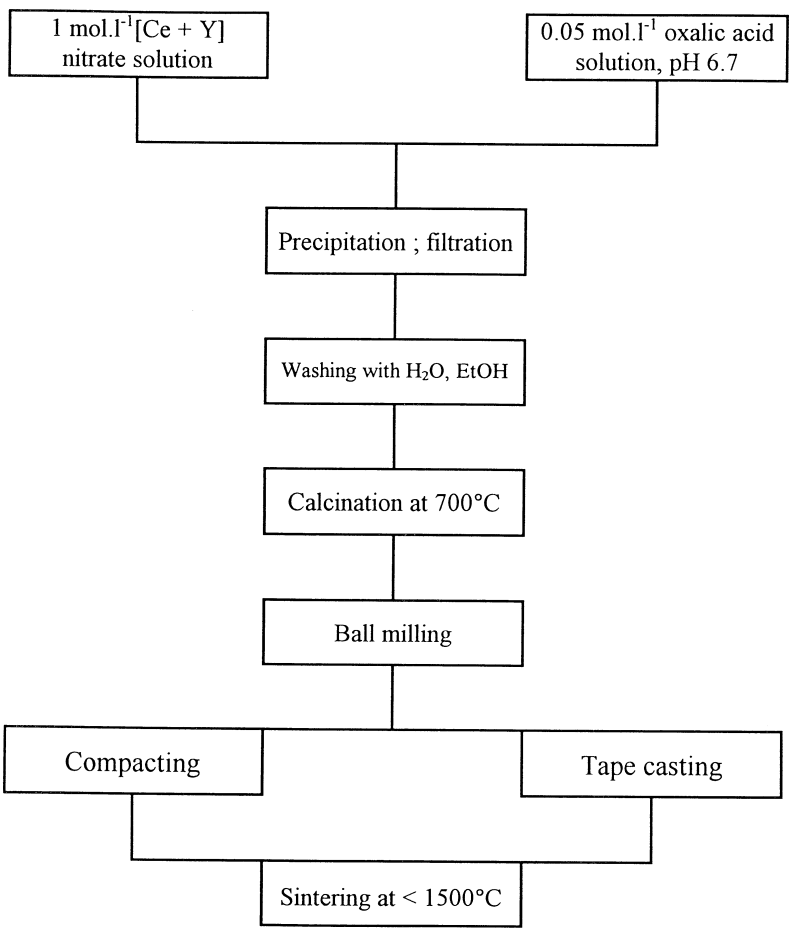

Fig. 1. Flow chart of the optimised oxalate coprecipitation route for preparation of sinterable doped ceria powder.

concentrations were prepared complexometrically (EDTA, xylenolorange indicator, acetate buffer). The concentrated $[\mathrm{Ce}+\mathrm{Y}]$-nitrate solution of 1 moll ${ }^{-1}$, mixed in the desired Ce: $\mathrm{Y}$ proportion, was added from a burette at $10 \mathrm{ml} \mathrm{m^{-1 }}$ under vigorous stirring to a dilute $0.05 \mathrm{moll}^{-1}$ oxalic acid solution, neutralised to $\mathrm{pH} 6.7$ by ammonium hydroxide. These optimal conditions were determined in the previous report. ${ }^{1}$ The filtrate was vacuum-filtered, treated with different washing solvents, dried overnight at $50^{\circ} \mathrm{C}$ and finally converted to the oxide. The calcination temperature was varied between 600 and $1000^{\circ} \mathrm{C}$ in order to control the surface area and investigate the shrinkage behaviour of the powder. The obtained oxide powders were checked by X-ray diffraction (XRD, $\mathrm{Cu} \mathrm{K} \mathrm{K}_{\alpha}$, Philips APD1700). $\mathrm{NaCl}$ was used as an internal standard for the lattice parameter determination. Crystallite sizes of the powders were estimated by the XRD line broadening technique (XRD-LB). For this purpose, the portions around the (111) diffraction peak at $2 \theta \approx 28.8^{\circ}$ and around the (220) peak at $2 \theta \approx 47.8^{\circ}$ of the diffractogram of YDC were slowly scanned from $2 \theta=26$ to $31^{\circ}$ and $2 \theta=45$ to $53^{\circ} \mathrm{C}$, respectively, at $0.01^{\circ}$ intervals and intensity counting of $4 \mathrm{~s}$ inter$\mathrm{val}^{-1}$. The diffraction peaks were subsequently (i) smoothed, (ii) deconvolved into the $\alpha_{1}-\alpha_{2}$ doublet using the Rachinger correction method, ${ }^{2}$ and (iii) corrected for instrumental broadening (GaussianGaussian, Warren formula) $)^{2,3}$ by software developed in-house. The (101) and (112) peaks of coarse $\mathrm{SiO}_{2}$ at $2 \theta \approx 26.8^{\circ}$ and $2 \theta \approx 50.3^{\circ} \mathrm{C}$ respectively, were used for the instrumental broadening correction. The crystallite size was calculated from the corrected halfwidth of the YDC-(111) and (220) peaks using the Scherrer formula. ${ }^{2,3}$

A study of the sintering behaviour of dopantrich compacts of $\mathrm{Ce}_{0.67} \mathrm{Y}_{0.33} \mathrm{O}_{1.83}$ (33YDC) was carried out separately and partly reported elsewhere. ${ }^{1,4}$ Additional observations will be described here.

Calcined powder of $\mathrm{Ce}_{0.8} \mathrm{Y}_{0.2} \mathrm{O}_{1.9}$ (20YDC, a composition close to that of maximum ionic conductivity) was formulated into a tape casting slurry either directly or after a ball milling step. Different ball milling procedures (for 12-24 h) were carried out: wet milling in isopropanol or acetone and dry milling, both with zirconia balls in zirconia jars or polyethylene containers. The particle size distribution (PSD, which yields average agglomerate size by volume) of each powder batch by the sedimentation-centrifugal technique (Centrifugal Particle Size Analyzer model SA-CP3, Shimadzu, Japan) was closely monitored.

A slurry formulation similar as for YSZ powder was used, as previously established in this laboratory: ${ }^{5}$ polyvinylbutyral binder (PVB), di-n-butylphtalate plasticizer (DBP), TritonX homogenizer (polyethylene glycol mono-p-isooctylphenyl ether), fish oil dispersant and organic solvent. The proportions of these components were varied, for $100 \mathrm{~g}$ of YDC powder, between 9-14 $\mathrm{g}$ of PVB, 9-14 $\mathrm{ml}$ of DBP, $2 \mathrm{ml}$ of TritonX, $2 \mathrm{ml}$ of fish oil, and $90-120 \mathrm{ml}$ of solvent (isopropanol-toluene mixture in the ratio 2:1). The amount of solvent and DBP followed approximately proportionally that of the PVB binder.

The YDC powder was first mixed with the homogenizer, dispersant, solvent and zirconia balls, and milled for $4-8 \mathrm{~h}$. Then the binder and plasticizer were added, and milling continued overnight. The homogenised slurry was poured into a glass container, de-aired under a mild vacuum to an adequate viscosity and finally cast under a blade setting of nominally $700-1100 \mu \mathrm{m}$ at a speed of $15 \mathrm{~cm} \mathrm{~min}^{-1}$ (equipment: Tsugawa Seiki, Model DP-150, Japan). Variation of the viscosity and of the binder proportion was studied.

After drying for $12 \mathrm{~h}$, discs of diameter 30 $60 \mathrm{~mm}$ were punched from the tapes, flipped and placed with the 'bottom face' of the tape directed upwards on a coarse YDC powder bed on alumina substrate plates. In a first low temperature heating cycle between room temperature and $350^{\circ} \mathrm{C}$, the 
organics were allowed to burn out slowly. In the second faster cycle, these 'dewaxed' samples were fired at temperatures ranging between 1300 and $1670^{\circ} \mathrm{C}$ for $2 \mathrm{~h}$.

Resulting densities of the sintered compacts of 33 YDC and of the tape cast discs of 20YDC, 20 to $40 \mathrm{~mm}$ in diameter and 150 to $250 \mu \mathrm{m}$ thick, were determined by the Archimedes method $\left(\mathrm{H}_{2} \mathrm{O}\right)$, and their microstructures investigated by scanning electron microscopy (SEM, Hitachi S-800, Japan).

\section{RESULTS}

\subsection{Coprecipitation optimisation}

Some details concerning the oxalate coprecipitation procedure not yet outlined in previous reports ${ }^{1,4}$ are useful to mention.

\subsubsection{Aqueous vs ethanolic oxalic acid solution.}

Oxalic acid is much more soluble in ethanol $(>4$ moll $\left.{ }^{-1}\right)$ than in water $\left(1.2 \mathrm{moll}^{-1}\right.$ without ammonia addition, $0.42 \mathrm{moll}^{-1}$ at neutral $\mathrm{pH}$ ). However, a very large excess of roughly seven times the stoichiometric amount of oxalic acid was found necessary to complete the precipitation reaction in ethanol, whereas the stoichiometric amount can be used in water. It is believed that this is due to the nondeprotonation of oxalic acid in alcohol, which is a less polar solvent than $\mathrm{H}_{2} \mathrm{O}$. It was demonstrated that highly concentrated oxalic acid solutions yield oxide powders of poor sinterability. ${ }^{1}$ YDC powders of typically several $\mu \mathrm{m}$ average agglomerate size were obtained from concentrated ethanolic solutions, whereas submicron YDC powder was routinely obtained from dilute aqueous solutions, leading to much improved sintering characteristics. In summary, because in ethanolic solution no $\mathrm{pH}$ control is possible and large oxalic acid excess is required, all-aqueous solutions are by far preferable.

\subsection{2 $\mathrm{pH}$ consideration}

Several reports using the oxalate coprecipitation bath carry out the reaction at neutral $\mathrm{pH}$ without specifying a reason. The $\mathrm{pH}$ of the solution is an important parameter as demonstrated earlier. ${ }^{1}$ With the known $\mathrm{pK}_{\mathrm{a}, 1}, \mathrm{pK}_{\mathrm{a}, 2}$ values of oxalic acid and $\mathrm{pK}_{\mathrm{b}}$ value of ammonia $\left(\mathrm{pK}_{\mathrm{a}, 1}=1.23\right.$, $\left.\mathrm{pK}_{\mathrm{a}, 2}=4.19, \mathrm{pK}_{\mathrm{b}}=4.75\right)$, the $\mathrm{pH}$ of a solution of any initial concentrations of the two reagents can be exactly calculated, as depicted in Fig. 2(a). Twice the molar amount of ammonium hydroxide is necessary to neutralize the oxalic acid solution.
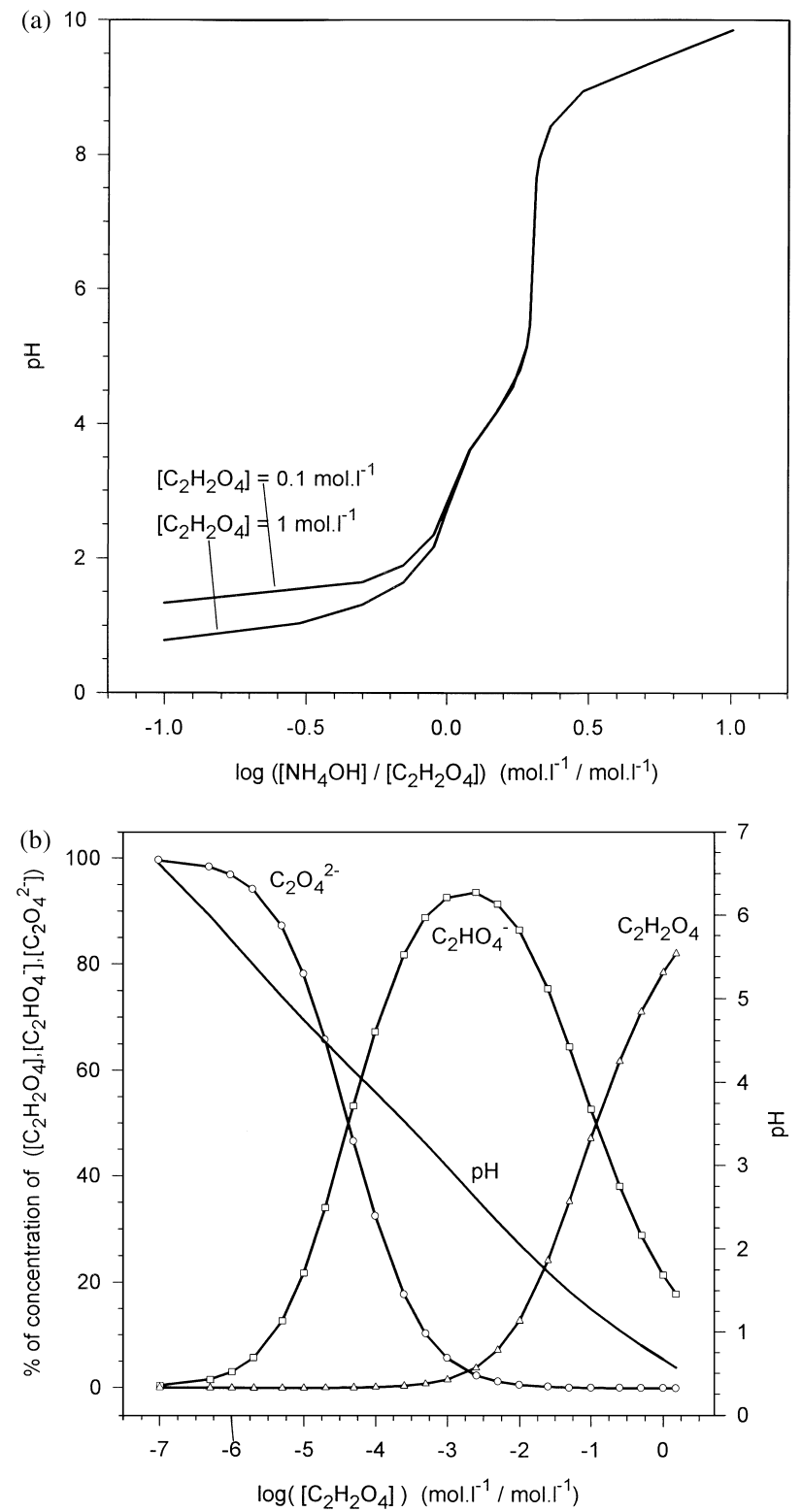

Fig. 2. (a) $\mathrm{pH}$ of an ammonium oxalate solution as a function of the initial concentration ratio $\left(\mathrm{NH}_{4} \mathrm{OH}\right) /\left(\mathrm{C}_{2} \mathrm{H}_{2} \mathrm{O}_{4}\right)$; (b) relative concentrations of molecules and ions in solution as a function of the initial oxalic acid concentration.

The calculated concentrations of the individual molecules and ions in solution $\left(\mathrm{C}_{2} \mathrm{H}_{2} \mathrm{O}_{4}\right),\left(\mathrm{C}_{2} \mathrm{HO}_{4}\right)$, $\left(\mathrm{C}_{2} \mathrm{O}_{4}{ }^{2-}\right)$ and $\left(\mathrm{H}^{+}\right)$as they vary with the initial oxalic acid concentration, are visualised in Fig. 2(b). It is sensible to conduct the precipitation reaction at a $\mathrm{pH}$ where mostly free $\left(\mathrm{C}_{2} \mathrm{O}_{4}{ }^{2-}\right)$ is available, at the same time not at a basic $\mathrm{pH}$ to avoid hydroxide precipitation, so that every batch was routinely monitored at a $\mathrm{pH}$ of around 6.5 .

\subsubsection{Solution mixing speed}

In a rough check, the speed of dropwise addition of the mixed $(\mathrm{Ce}+\mathrm{Y})$-nitrate solution from the buret to the stirred neutral oxalic acid solution, was varied between 1 and $50 \mathrm{ml} \mathrm{min}{ }^{-1}$. No difference in resulting oxide powder agglomerate size or fired 
density of compacts was observed. An intermediate addition speed of $10-20 \mathrm{ml} \mathrm{min}^{-1}$ was arbitrarily chosen for all subsequent experiments. Vigorous stirring of the oxalic acid solution, on the contrary, was a necessity.

\subsubsection{Washing treatment of the precipitate}

A standard coprecipitated batch prepared under the optimized conditions of $1 \mathrm{moll}^{-1}(\mathrm{Ce}+\mathrm{Y})$ and neutral $0.05 \mathrm{moll}^{-1} \quad \mathrm{H}_{2} \mathrm{C}_{2} \mathrm{O}_{4}$, was divided into three equal parts, each of which received a different washing treatment: (i) first $\mathrm{H}_{2} \mathrm{O}$, then $\mathrm{EtOH}$; (ii) first $\mathrm{H}_{2} \mathrm{O}$, then an 'ATA' washing step (acetonetoluene-acetone), reported to be effective in improving powder characteristics; $;, 7$ (iii) $\mathrm{H}_{2} \mathrm{O}$ only. All three precipitates were then in the usual way dried overnight $\left(50^{\circ} \mathrm{C}\right)$, calcined at $700^{\circ} \mathrm{C}(1 \mathrm{~h})$, pressed into compacts at $200 \mathrm{MPa}$ and fired at $1500^{\circ} \mathrm{C}(4 \mathrm{~h})$. Figure 3 shows SEM graphs of fracture surfaces of such samples. An advantage for the organics-washed samples is demonstrated, showing the densest microstructure. Measured densities were $97.1 \%$ for the ethanol- and ATAtreated cases, but only $95.1 \%$ for the water-washed samples. This observation was somewhat unexpected as oxalates were reported before to be rather insensitive to the washing treatment. ${ }^{6}$ In retrospect, the ethanol-wash also serves as a quality test for the expected oxide powder characteristics. If the precipitate became fluffy upon flushing with ethanol, it was found to be of large average agglomerate size (several $\mu \mathrm{m}$ ) and poor sinter- ability after calcination. If on the contrary no visible change was noticed during washing of the precipitate cake with ethanol, a finer (submicron) powder with improved sintering behaviour could be expected.

Figure 4 resummarizes the above results and those of the earlier report, ${ }^{1}$ illustrating that only the combined use of a particular set of coprecipitation bath parameters yields sinteractive powder after calcination. Four cases are presented: (i) dilute $(\mathrm{Ce}+\mathrm{Y})$ nitrate solution $0.05 \mathrm{moll}^{-1}$ in dilute neutral acid $0.06 \mathrm{moll}^{-1}$, sintered from as calcined [Fig. 4(a)] and milled powder [Fig. 4(b)]; (ii) concentrated $(\mathrm{Ce}+\mathrm{Y})$ nitrate $1 \mathrm{moll}^{-1}$ in concentrated neutral oxalic acid $0.41 \mathrm{moll}^{-1}$, sintered from as calcined [Fig. 4(c)] and milled powder [Fig. 4(d)]; (iii) concentrated $(\mathrm{Ce}+\mathrm{Y})$ nitrate $1 \mathrm{moll}^{-1}$ in dilute oxalic acid $0.06 \mathrm{moll}^{-1}$ at a low $\mathrm{pH}$ of 2, sintered from as calcined powder [Fig. 4(e)]; (iv) concentrated $(\mathrm{Ce}+\mathrm{Y})$ nitrate $1 \mathrm{moll}^{-1}$ in dilute neutral oxalic acid $0.06 \mathrm{moll}^{-1}$, sintered from as calcined powder [Fig. 4(f)].

The best overall result is obtained for the as-calcined powder of case (iv). For the other cases, not even a standard wet milling step (in isopropanol) could 'repair' the ill-sinterability of powders prepared under unfavourable conditions of dilute metal nitrate solution, concentrated oxalic acidsolution, or low solution $\mathrm{pH}$.

It thus appears that in a solution of either very concentrated $\left(\mathrm{C}_{2} \mathrm{O}_{4}{ }^{2-}\right)$ (corresponding to highly concentrated oxalic acid solution at neutral $\mathrm{pH}$ ) or

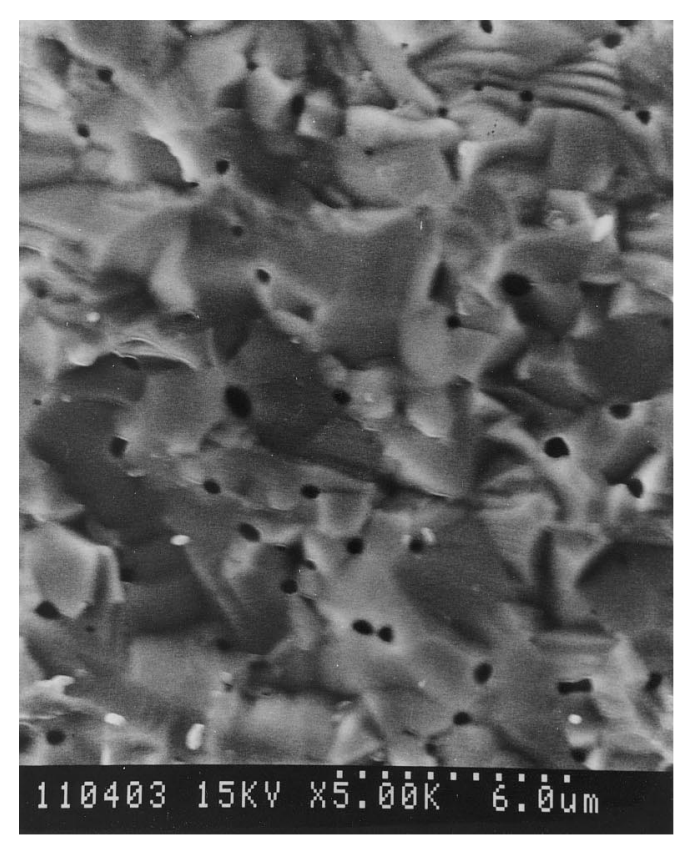

(a)

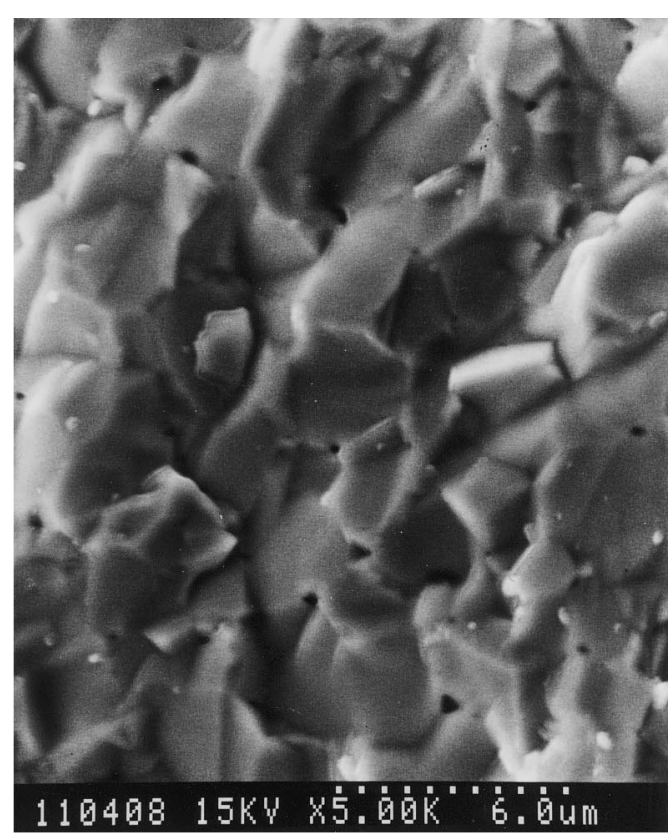

(b)

Fig. 3. SEM fracture surfaces of sintered 33 YDC pellets $\left(1500^{\circ} \mathrm{C}, 4 \mathrm{~h}\right)$, pressed from powders calcined from oxalate precursors that were washed (a) with water only and (b) with water and an organic solvent (alcohol, acetone-toluene). 


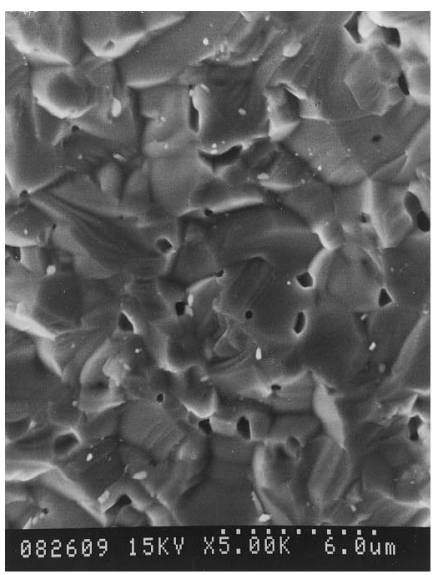

(a)

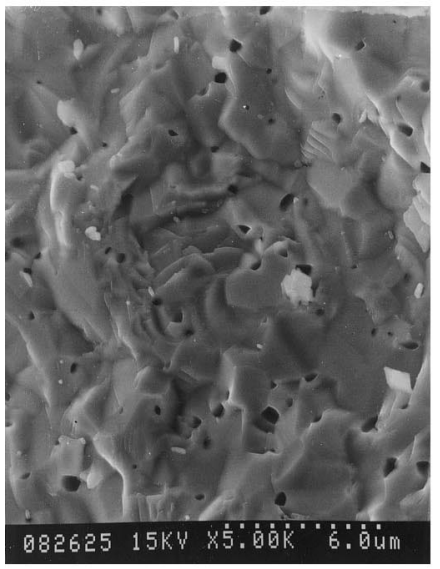

(b)

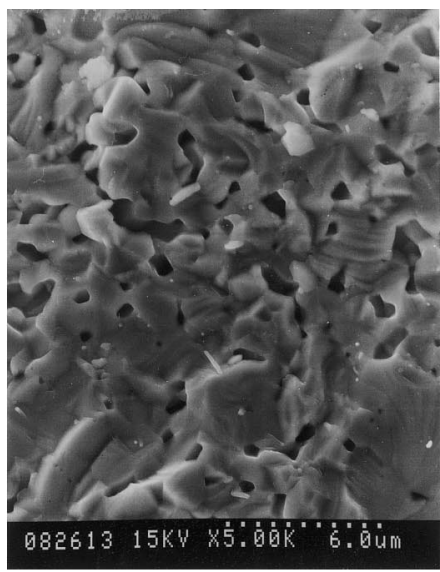

(c)

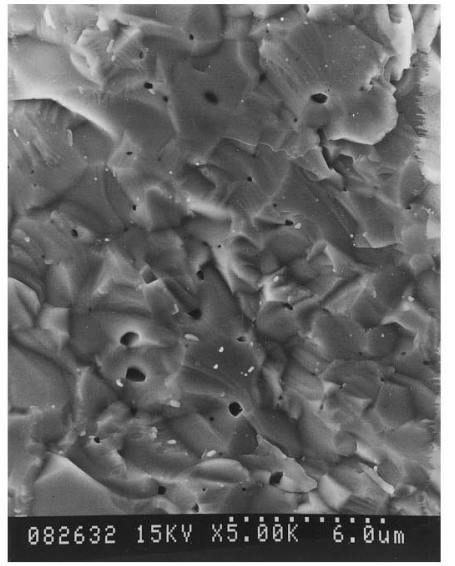

(d)

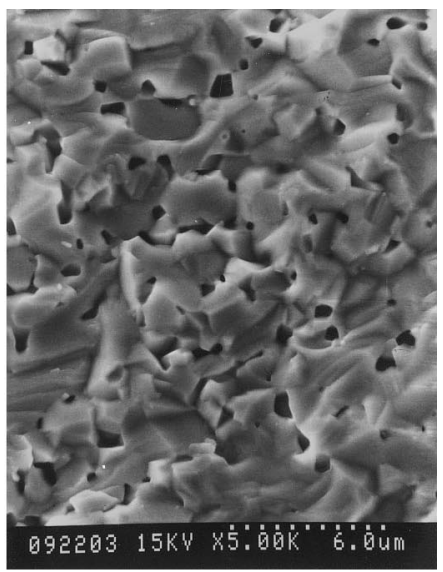

(e)

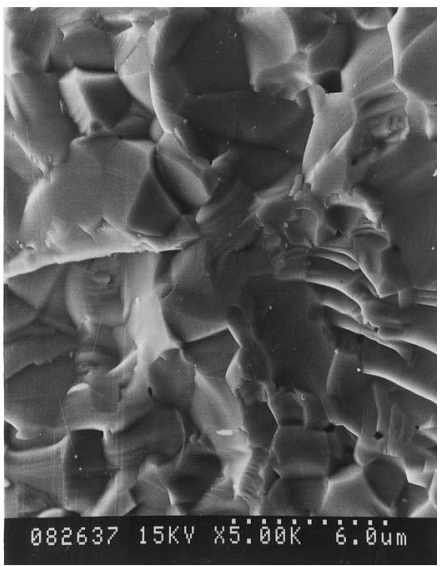

(f)

Fig. 4. SEM fracture surfaces of sintered pellets $\left(1500^{\circ} \mathrm{C}, 4 \mathrm{~h}\right)$ pressed from powders used after calcination $(\mathrm{a}, \mathrm{c}, \mathrm{e}, \mathrm{f})$ or a wet milling step (b, d) and obtained from different coprecipitation bath conditions: $(\mathrm{a})\left(\mathrm{C}_{2} \mathrm{H}_{2} \mathrm{O}_{4}\right)=0.06 \mathrm{moll}^{-1},(\mathrm{Ce}+\mathrm{Y})=0.05 \mathrm{moll}{ }^{-1}$, $\mathrm{pH}$ 6.7 , as calcined; (b) $\left(\mathrm{C}_{2} \mathrm{H}_{2} \mathrm{O}_{4}=0.06 \mathrm{moll}^{-1}, \quad(\mathrm{Ce}+\mathrm{Y})=0.05 \mathrm{moll}^{-1}, \mathrm{pH}\right.$ 6.7, wet milled; (c) $\left(\mathrm{C}_{2} \mathrm{H}_{2} \mathrm{O}_{4}\right)=0.41 \mathrm{moll}^{-1}$, $(\mathrm{Ce}+\mathrm{Y})=1 \mathrm{moll}^{-1}$, pH 6.7, as calcined; (d) $\left(\mathrm{C}_{2} \mathrm{H}_{2} \mathrm{O}_{4}\right)=0.41 \mathrm{moll}^{-1}$, $(\mathrm{Ce}+\mathrm{Y})=1$ mol 1-1, $\mathrm{pH} 6.7$, wet milled; (e) $\left.\mathrm{C}_{2} \mathrm{H}_{2} \mathrm{O}_{4}\right)=0.06 \mathrm{moll}^{-1},(\mathrm{Ce}+\mathrm{Y})=1 \mathrm{moll}^{-1}, \mathrm{pH} 2$, as calcined; $(\mathrm{f})\left(\mathrm{C}_{2} \mathrm{H}_{2} \mathrm{O}_{4}\right)=0.06 \mathrm{moll}^{-1},(\mathrm{Ce}+\mathrm{Y})=1 \mathrm{moll}{ }^{-1}$, $\mathrm{pH} 6.7$, as calcined.

of very dilute $\left(\mathrm{C}_{2} \mathrm{O}_{4}{ }^{2-}\right)$ (corresponding to an aqueous solution of low pH, Fig. 2, or to an ethanolic solution), a well mixed oxalate coprecipitate could not be obtained. Principally, separation of the oxalates is possible since the solubility products of yttrium oxalate and cerous oxalate are one to two orders of magnitude apart. ${ }^{8}$ Nevertheless, this finding is somewhat unexpected since the reverse strike mixing method is employed (addition of the metal ions solution to the precipitating agent rather than vice-versa). Every reaction was conducted to completion and never was any additional precipitate observed from the supernatant after filtration. EDX analysis of the bulk of sintered samples during SEM observation always confirmed the desired $\mathrm{Ce}-\mathrm{Y}$ oxide composition.

Table 1 compares the results and important parameters of this work with those of other reports $^{9-13}$ where doped ceria powder was prepared by an oxalate coprecipitation method. In

Table 1. Comparison of oxalate coprecipitation procedures from the literature with this work (data for pressed compacts

\begin{tabular}{|c|c|c|c|c|c|c|c|c|}
\hline Ref. & Composition & $\begin{array}{c}\left(\mathrm{C}_{2} \mathrm{H}_{2} \mathrm{O}_{4}\right) \\
\mathrm{mol} \mathrm{L}^{-1}\end{array}$ & $\begin{array}{c}(\mathrm{Ce}+\mathrm{Me}) \\
\mathrm{mol} \mathrm{L}^{-1}\end{array}$ & $\mathrm{pH}$ & $\begin{array}{l}\text { Washing } \\
\text { treatment }\end{array}$ & Calcination & Sintering & $\begin{array}{l}\text { Density } \\
\text { (\%) }\end{array}$ \\
\hline 9 & CaDC,YDC & 0.39 & & 6.5 & & $1000^{\circ} \mathrm{C}$ & $1600^{\circ} \mathrm{C}^{2 \mathrm{~h}^{-1}}$ & 95 \\
\hline 10 & $18 \mathrm{GdDC}$ & 0.42 & 0.1 & 6 & No & & $1700^{\circ} \mathrm{C} 2 \mathrm{~h}^{-1}$ & \\
\hline 11 & $18 \mathrm{GdDC}$ & 0.39 & & 6.5 & & $1000^{\circ} \mathrm{C}$ & $1300^{\circ} \mathrm{C} 10 \mathrm{~h}^{-1}$ & \\
\hline 12 & $15 \mathrm{GdDC}$ & 0.39 & 0.3 & 6.5 & i-propanol & $800^{\circ} \mathrm{C}$ & $1400^{\circ} \mathrm{C} 4 \mathrm{~h}^{-1}$ & 98 \\
\hline 13 & GdDC & 0.39 & & 6 & Organic & $750^{\circ} \mathrm{C}$ & $\begin{array}{l}1300^{\circ} \mathrm{C} 4 \mathrm{~h}^{-1} \\
1550^{\circ} \mathrm{C}\end{array}$ & $\begin{array}{r}88 \\
95-98\end{array}$ \\
\hline This work & 10-33YDC & 0.05 & 1 & 6.7 & Alcohol & $700^{\circ} \mathrm{C}$ & $1300^{\circ} \mathrm{C} 4 \mathrm{~h}^{-1}$ & 98 \\
\hline
\end{tabular}

CaDC, YDC, GdDC: calcium-, yttrium-, gadolinium-doped ceria. 
(a)

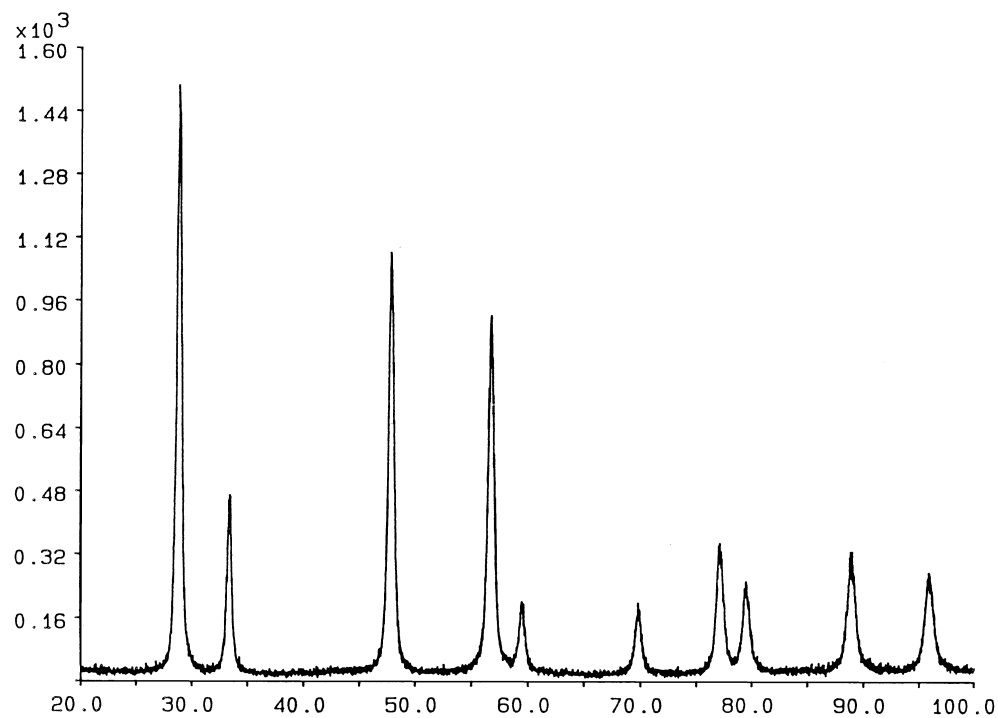

(b) $\times 10^{3}$

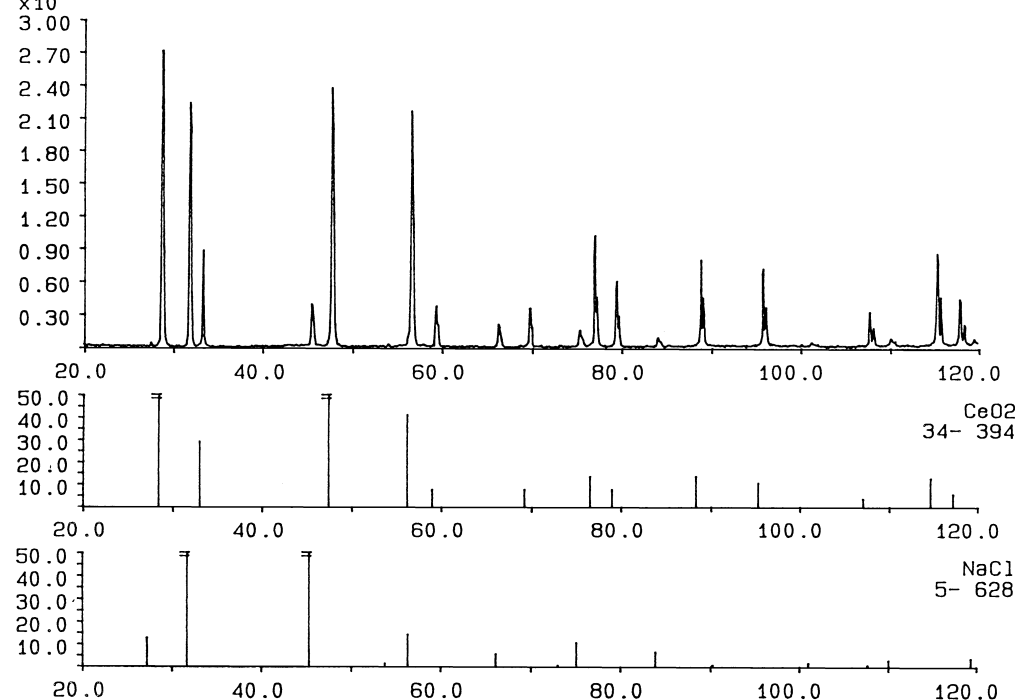

(c)

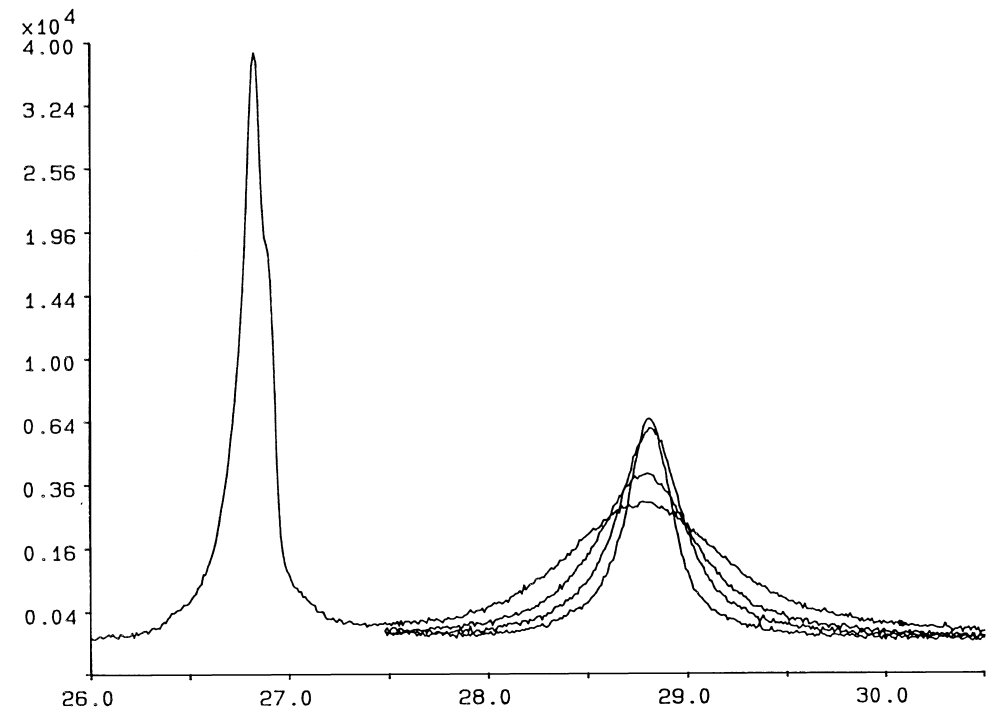

Fig. 5. (a) Powder X-ray diffractogram of $\mathrm{Ce}_{0.667} \mathrm{Y}_{0.333} \mathrm{O}_{1.833}$ calcined at $700^{\circ} \mathrm{C}$. Intensity counts vs $2 \theta$ scaling is shown; (b) powder X-ray diffractogram of coarse $\mathrm{Ce}_{0.667} \mathrm{Y}_{0.333} \mathrm{O}_{1.833}$, obtained from grinding a pellet sintered at $1500^{\circ} \mathrm{C}$. The powder was mixed with a coarse $\mathrm{NaCl}$ standard. JCPDS reference patterns of $\mathrm{CeO}_{2}$ and $\mathrm{NaCl}$ are indicated. Scaling as in (a); (c) illustration of XRD-line broadening for the (111) reflection at $2 \theta=28.8^{\circ}$ of $33 \mathrm{YDC}$ powder calcined at 600 (broadest line), 700,800 and $900^{\circ} \mathrm{C}$ (narrowest line). The (101) reflection of coarse $\mathrm{SiO}_{2}$ quartz at $2 \theta=26.8^{\circ}$ is used for instrumental broadening correction. Intensity counts vs $2 \theta$ scaling. 
view of the reasons just discussed, an explanation for the inferior results of those studies is suggested: the use of too-concentrated oxalic acid solution was likely responsible for the lesser sintering quality of those oxide powders when compared to our data.

\section{$3.2 \times R D$}

Figure 5(a) shows the X-ray diffractogram of $33 \mathrm{YDC}$ after calcination at $700^{\circ} \mathrm{C}(\mathrm{lh})$. Figure 5(b) shows the data of coarse 33YDC, obtained after sintering a compact $\left(1500^{\circ} \mathrm{C}\right)$ which was crushed and ground with a coarse $\mathrm{NaCl}$ standard. The reference patterns of pure $\mathrm{NaCl}$ and $\mathrm{CeO}_{2}$ are also indicated in the figure. From data as in Fig. 5(b), the lattice parameters and X-ray densities of YDC powders of different yttrium content were determined. It is noted that the YDC peaks in Fig. 5(a) are considerably broader than in Fig. 5(b) due to the fine crystallite size of the powder. The primary crystallite size of the powder naturally increased with calcination temperature, as qualitatively shown in the X-ray diffractrogram detail of Fig. 5(c). The quantitative estimate from this figure is displayed in Fig. 6. Nano-sized powder was produced. This allows control of the surface area, an important parameter in tape casting.

\subsection{Sintering behaviour of compacts}

\subsubsection{Compaction pressure}

From a standard batch of well sinterable powder, pellets were compacted at different pressures

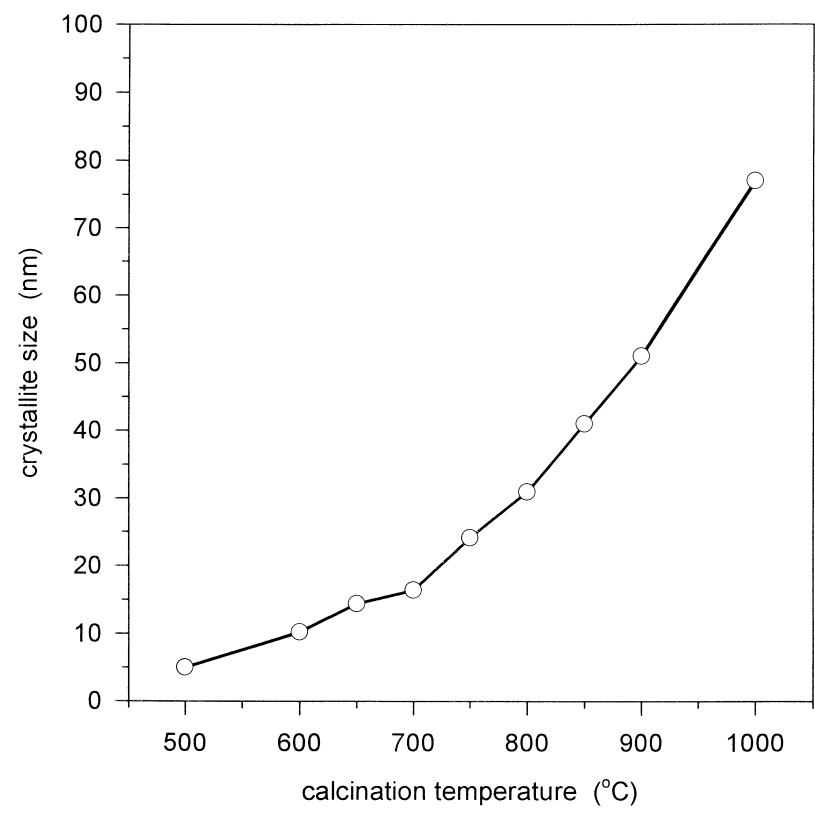

Fig. 6. Primary particle size of $33 Y D C$ powders calcined at different temperatures, as obtained from XRD-LB estimation.

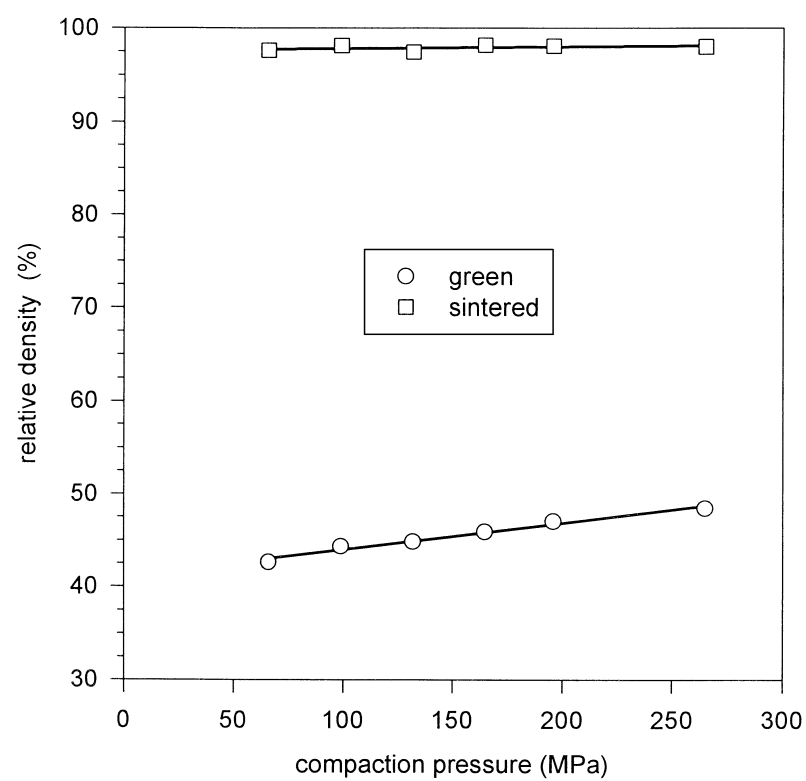

Fig. 7. Relative green and sintered density of 33YDC pellets $\left(1500^{\circ} \mathrm{C}, 4 \mathrm{~h}\right)$ as a function of the compaction pressure.

between 66 and $266 \mathrm{MPa}$. Measured green densities and fired densities $\left(1500^{\circ} \mathrm{C}\right.$ for $\left.4 \mathrm{~h}\right)$ in $\%$ relative to theoretical of such samples are depicted in Fig. 7. No influence on the fired density was detected, in contrast to findings in other works, where acceptable densities were obtained only at very high compaction pressures around 1000 MPa. ${ }^{10,11}$

The fact that also samples of relatively low green density just above $40 \%$ were readily densified, should prove promising for the tape cast formulation, where application of a compacting pressure is absent and lower green densities of typically 35$40 \%$ are achieved because of the organics added to the tape casting slurry.

\subsubsection{Shrinkage}

The absolute and differential shrinkage curves of compacts of YDC powder, calcined at temperatures between 600 and $900^{\circ} \mathrm{C}$, were measured in a thermomechanical analysis apparatus (TMA320, Seiko Instruments Series SSC/5200, Japan), in air, room temperature to $1400^{\circ} \mathrm{C}$ at $5^{\circ} \mathrm{C} \mathrm{min}^{-1}$, alumina rod weight. These are displayed in Fig. 8(a). The powders start to sinter early, at about $100^{\circ} \mathrm{C}$ above the temperature at which they were calcined. For a calcination temperature $\leq 700^{\circ} \mathrm{C}$, a pronounced maximum in the shrinkage rate was present in the lower temperature region (Fig. 8(b)). As suggested before, ${ }^{12}$ this is probably explained by the sintering of the primary particles to denser agglomerates, thereby eliminating the intra-agglomerate pores. Once this process is completed, the densification slows down. Only at higher, normal sintering temperatures $\left(\geq 1200^{\circ} \mathrm{C}\right)$ may a second 

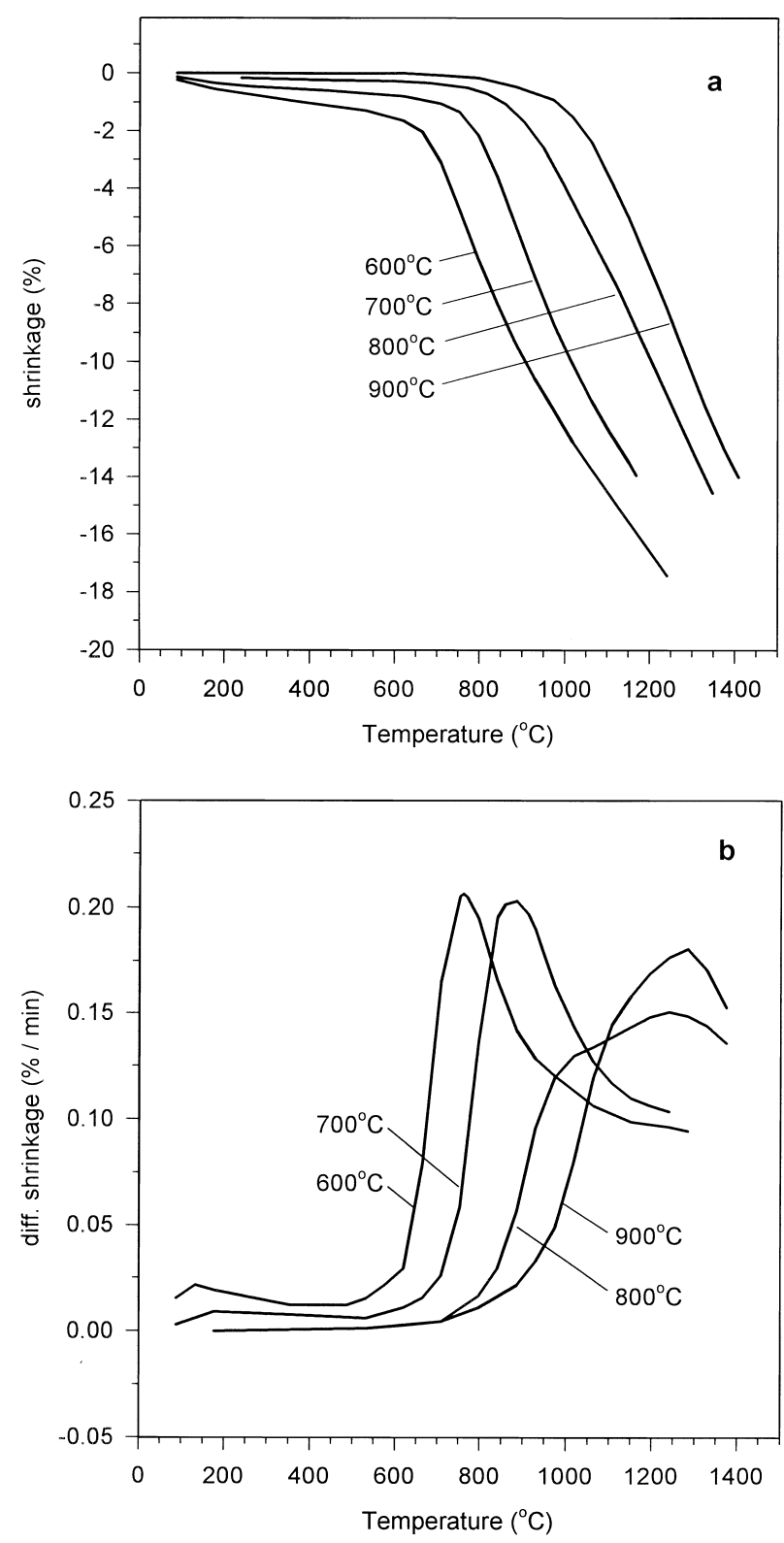

Fig. 8. Shrinkage behaviour of pellets from YDC powders that were calcined at different temperatures, indicated in the figures: (a) relative linear shrinkage; (b) differential shrinkage.

maximum be observed, where the larger interaagglomerate pores are eliminated and the pellet shrinks to a fully dense body. This maximum of the high temperature region is observed with the powder calcined at $900^{\circ} \mathrm{C}$. For calcination temperatures around $800^{\circ} \mathrm{C}$, an overlapping behaviour is recorded, featuring a rather broad maximum between $1000-1300^{\circ} \mathrm{C}$. The shrinkage curves could not be studied to higher temperatures (1400$1500^{\circ} \mathrm{C}$ ), because of temperature limitations of the apparatus.

In summary, it appears that below $800^{\circ} \mathrm{C}$ nanocrystallites arranged within agglomerates already sintered together to form dense hard particles of larger size. This explains the low temperature maximum of the shrinkage curves (Fig. 8(b)), and a drop in surface area as exemplified further below.
It also explains another observation of a technical nature, which was often encountered during compaction of the powders. Powders calcined at $<750^{\circ} \mathrm{C}$ were always very easily compacted and never cracked at any stage. From calcination temperatures of $750^{\circ} \mathrm{C}$ upwards, pressing became increasingly difficult, the pellets often breaking apart either during compaction itself or else during sintering afterwards. The presence of hard agglomerates formed by intra-agglomerate sintering of primary particles during calcination at > $700^{\circ} \mathrm{C}$ of such powders would aggravate the subsequent compaction into pellets, often leading to cracks. A slight drop in density (from 99 to $98 \%$ ) for sintered pellets of powders calcined at those higher temperatures may be accounted for by this fact.

\subsection{Tape casting}

\subsubsection{Ball milling}

As-calcined, wet milled (in isopropanol) and dry milled powder batches were used for tape casting. Whereas wet milling was initially employed routinely to homogenize and reduce the powder agglomerate size and thereby improve the sinterability of pressed compacts at low temperature, ${ }^{4}$ it proved insufficient for low temperature sintering of cast tapes. ${ }^{1}$ Dry milling was found a much more suitable processing step for the doped ceria powder batches. The mean agglomerate sizes averaged to $0.75 \pm 0.05 \mu \mathrm{m}, 0.50 \pm 0.01 \mu \mathrm{m}$ and $0.35 \pm 0.02 \mu \mathrm{m}$ for calcined, wet milled and dry milled powder, respectively, over the calcination temperature range between 600 and $1000^{\circ} \mathrm{C}$. Whereas dry milling left the original ivory coloured powder unchanged in appearance, wet milling in isopropanol or acetone darkened the doped ceria to beige-brown. A possible carbon contamination and resulting bloating at high sintering temperatures may explain the inferiority of wet milled powder, in addition to its slightly larger agglomerate size, when compared with the dry milling process.

\subsubsection{Surface area}

The BET surface areas of calcined and milled powders were routinely checked (Shimadzu Model 2200, Japan). The variation of this value with calcination temperature follows largely the expected trends, as plotted in Fig. 9. The highest surface areas were found for the dry milled powders, and surface areas decreased with increasing temperature for all powders. The sudden drop between 700 and $800^{\circ} \mathrm{C}$ was explained above by primary crystallite sintering within agglomerates. 


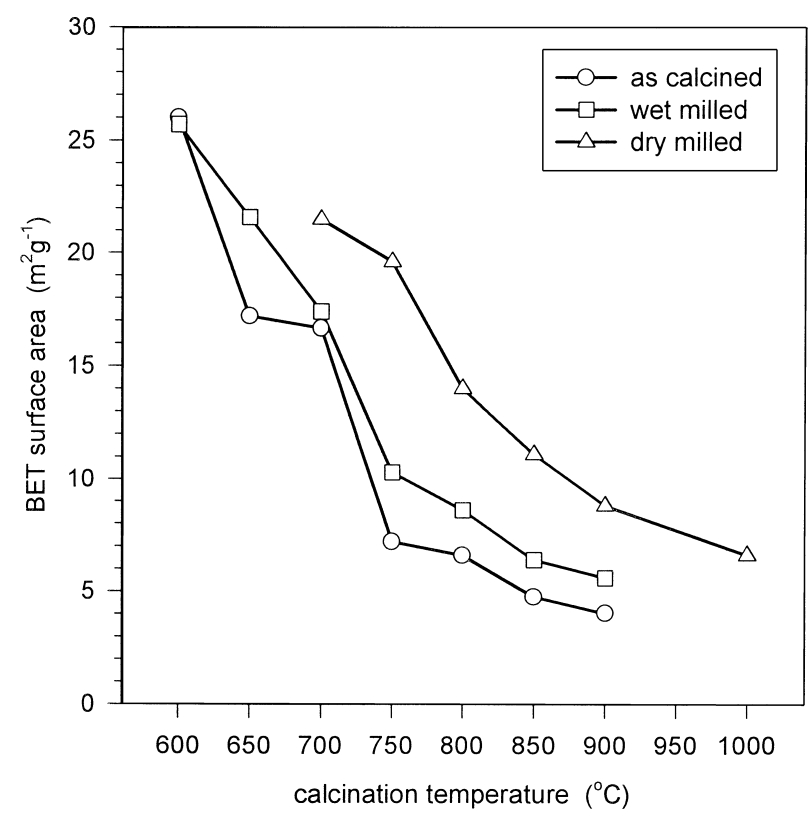

Fig. 9. BET surface area of $20 \mathrm{YDC}$ powder after calcination at different temperatures and after ball milling.

\subsubsection{SEM analysis}

The results obtained for tape casting of the different 20YDC starting powders is illustrated in the following for various cases by a study of the microstructure. The calcination temperature was chosen as $800^{\circ} \mathrm{C}$ if not stated otherwise, since this yielded surface areas of around $10 \mathrm{~m}^{2} \mathrm{~g}^{-1}$ (Fig. 9) as typically employed in tape casting. The residence time at the different sintering temperatures was $2 \mathrm{~h}$.

As-calcined powder directly formulated into a tape cast slurry without a prior milling step, could not be densified at any temperature, maximizing to $90 \%$ of theoretical at the highest temperature $\left(1670^{\circ} \mathrm{C}\right)$ used in this work.

Wet milled powder could be sintered to gas-tight membranes only at the highest temperatures $\left(1650-1670^{\circ} \mathrm{C}\right)$, e.g. to $95-96 \%$ of theoretical at $1670^{\circ} \mathrm{C}$, but to only $91 \%$ at $1500^{\circ} \mathrm{C}$.

Dry milled powder of $\leq 0.35 \mu \mathrm{m}$ average size could always be fired to high density, also at lower temperatures, e.g. to $98 \%$ at $1400^{\circ} \mathrm{C}$ and $99 \%$ at $1500^{\circ} \mathrm{C}$, regardless of the BET surface area-and hence the calcination temperature - of the powder. Indeed, powders calcined between 700 and $1000^{\circ} \mathrm{C}$, showing surface areas of 21 down to $6 \mathrm{~m}^{2} \mathrm{~g}^{-1}$ (Fig. 9), were sintered to similarly dense tapes using essentially the same slurry. This observation should not surprise, since also YSZ (yttria stabilized zirconia) powders with surface areas between 4 and $16 \mathrm{~m}^{2} \mathrm{~g}^{-1}$ had been routinely cast with the same slurry in this laboratory. The only alteration was a slight increase of binder (and parallel to this of plasticizer and solvent) for the powders of higher surface area.

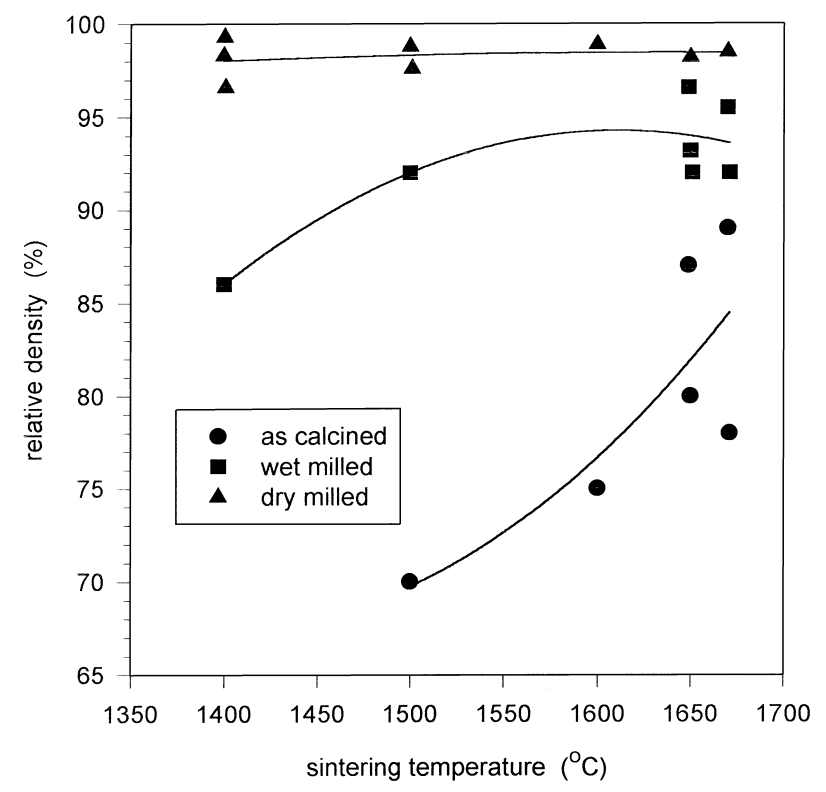

Fig. 10. Relative densities of sintered 20YDC tapes, cast from slurries with different starting powders as indicated.

Figure 10 summarizes the density data graphically. Figures 11-13 display SEM graphs of surfaces and fracture edges of the different tapes. Figures 11-13 shows the result for sintering at the highest temperature, $1670^{\circ} \mathrm{C}$, of tapes cast from the three different starting powders 'as-calcined' [Fig. 11(a), (b), 90\% dense], wet milled [Fig. 11(c), (d), 96\%] and dry milled [Fig. 11(e), (f), 99\%]. Figure 12 shows inferior tapes, fired at temperatures lower than the maximum $\left(1670^{\circ} \mathrm{C}\right)$, cast from 'as-calcined' [Fig. 12(a), (b), $1600^{\circ} \mathrm{C}, 75 \%$ dense] and wet milled powders [Fig. $12(\mathrm{c}),(\mathrm{d}), 1500^{\circ} \mathrm{C}, 91 \%$ ]. Figure 13 finally shows superior tapes cast from dry milled powder and fired at temperatures lower than the maximum $\left(1670^{\circ} \mathrm{C}\right): 1600^{\circ} \mathrm{C}$ [Fig. $13(\mathrm{a}),(\mathrm{b}), 99 \%$ dense], $1500^{\circ} \mathrm{C}$ [Fig. $13(\mathrm{c}),(\mathrm{d}), 99 \%$ ], $1400^{\circ} \mathrm{C}$ [Fig. 13(e), (f), 98\%], and $1300^{\circ} \mathrm{C}$ [Fig. 13(g), (h), $93 \%$ ]. It is noted that even for a short sintering time $(2 \mathrm{~h})$ at $1300^{\circ} \mathrm{C}$, densification of the membrane has started. By increasing the sintering time at maximum temperature, the final density is improved to gas tightness. This was confirmed by sintering 20YDC tapes to $1300^{\circ} \mathrm{C}$ for $10 \mathrm{~h}$, resulting in impervious $95 \%$ dense membranes. This is the lowest temperature yet reported for the densification of tape cast doped ceria.

\subsubsection{Slurry viscosity}

A large slurry batch with previously dry milled powder was divided into equal portions, each of which was de-aired down to a particular viscosity. In this way, the role of the viscosity at which the slurry was cast, was studied. From each tape portion, discs were punched and fired to $1400^{\circ} \mathrm{C}$ for 


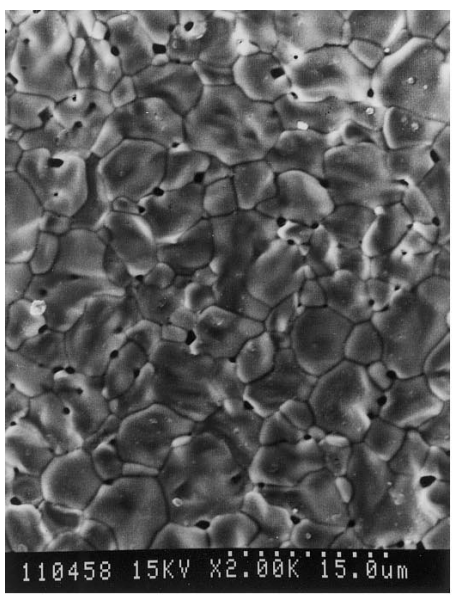

(a)

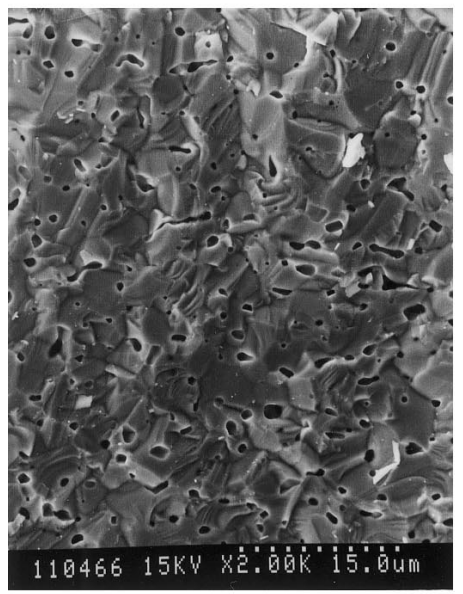

(b)

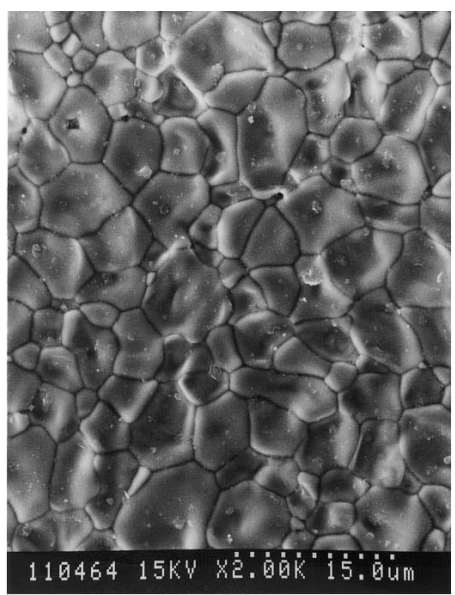

(c)

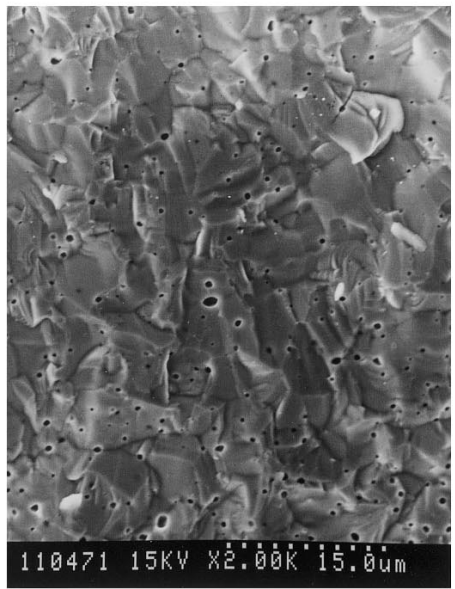

(d)

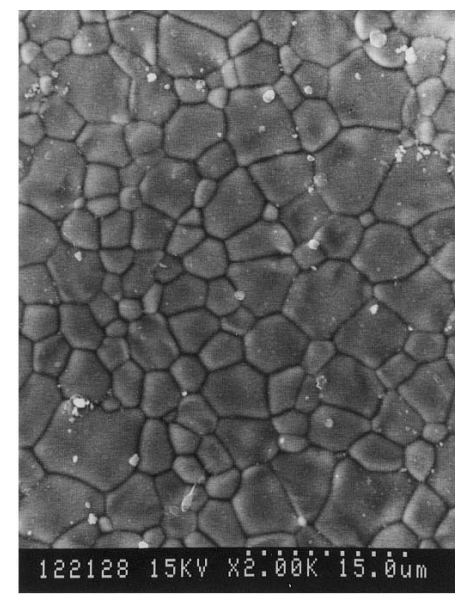

(e)

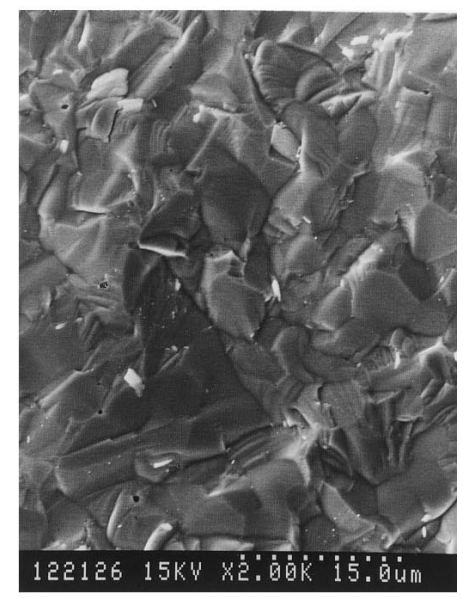

(f)

Fig. 11. SEM graphs of surface views (a, c, e) and fracture surfaces (b, d, f) of sintered 20YDC tapes $\left(1670^{\circ} \mathrm{C}, 2 \mathrm{~h}\right)$ from: $(\mathrm{a}, \mathrm{b})$ as calcined starting powder; (c, d) wet milled starting powder in isopropanol; $(\mathrm{e}, \mathrm{f})$ dry milled powder.

$2 \mathrm{~h}$. No difference in fired density was observed, averaging to $98.5 \% \pm 0.7 \%$ for slurry viscosities of 1-9 Pa.s. However, at low viscosities of 1 Pa.s, too much solvent had yet to evaporate off the cast tape so that often ripples were formed on its surface during drying. These tapes can be densified in the usual way, but the surfaces of the sintered discs then showed not a smooth, but a patterned appearance. At high viscosities of 6-7 Pa.s, the paste becomes too thick-flowing, with the risk of creating unevenness or stripes in the cast film. On the other hand, membranes cast at low viscosity tend to remain flatter upon 'dewaxing' of the organics (and subsequent firing) than membranes cast at high viscosity, which tend to warp more. Hence an intermediate viscosity value of $\approx 2-3$ $\mathrm{Pa}$.s was determined as the most appropriate, to give samples both flatter and with smooth surfaces.

\subsection{Slurry binder content}

For a large powder batch from dry milled powder, several slurries were prepared each of which contained a different amount of PVB binder and
DBP plasticizer. Powder-to-binder ratios (by weight) of 7, 8, 9, 10 and 11 were prepared, and all slurries cast at similar viscosities of 2-3 Pa.s. Again the amount of binder did not affect the fired density, but rather the smoothness and flatness of the sintered tapes. At too-low binder content (powder-to-binder ratio 11), cast films sometimes cracked after drying, and also tended to warp substantially in the dewaxing stage. Increasing the binder content keeps the samples flatter during burnout of the organics. Also, a higher binder content gives the cast film a sticky surface after drying, which is useful for adhesion of electrodes or other electrolyte layers (e.g. thin YSZ) that may be cast on top of the doped ceria green film. Without this adhesion between layers in the green state, good bonding after firing is unlikely to be achieved. Higher binder content increases significantly the linear shrinkage of the membrane at the burnout stage, a factor which has to be taken into account in particular for multiple layer casting: powder-tobinder ratios in the multiple layers should lie very close to each other. 


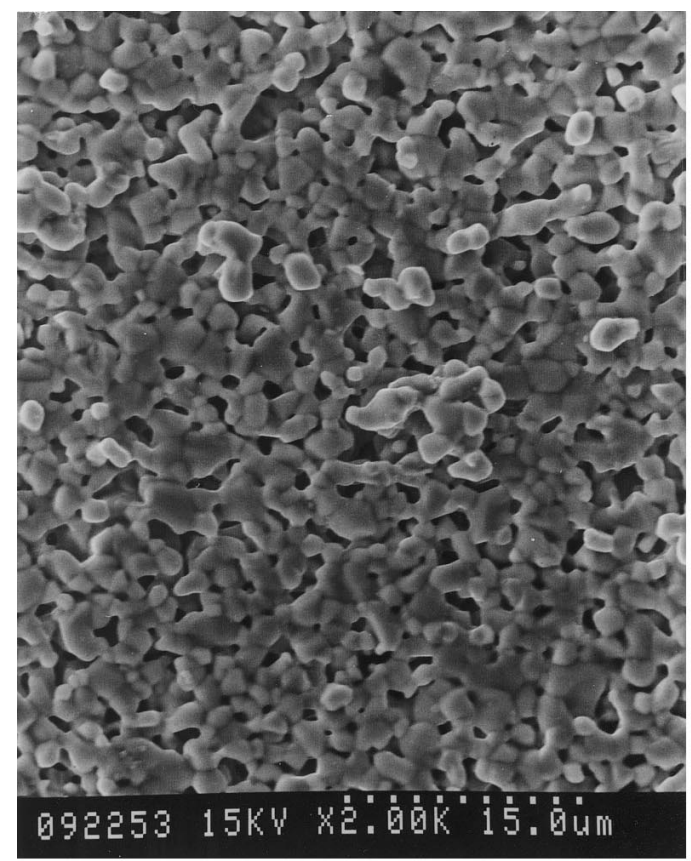

(a)

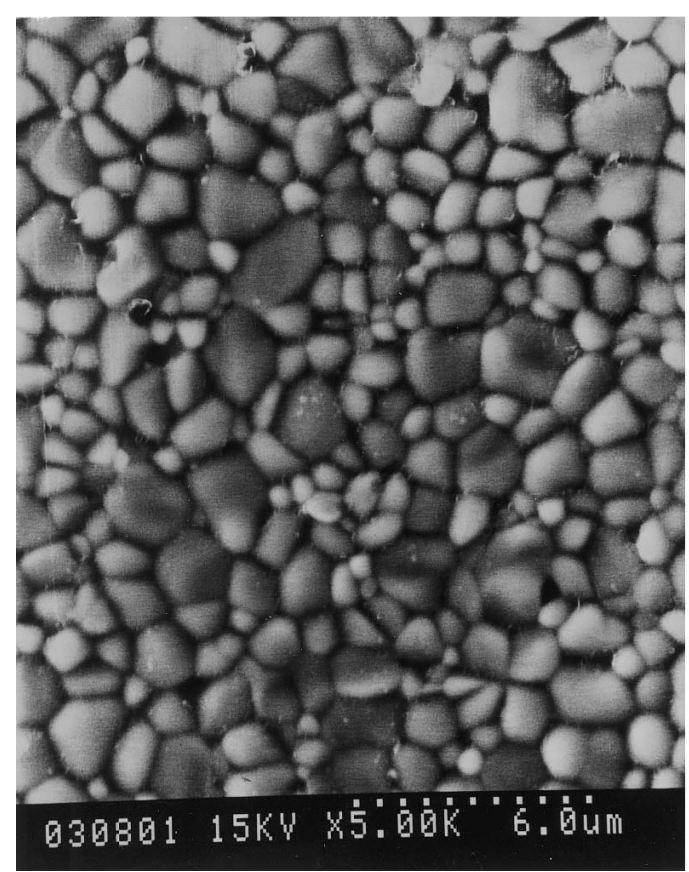

(c)

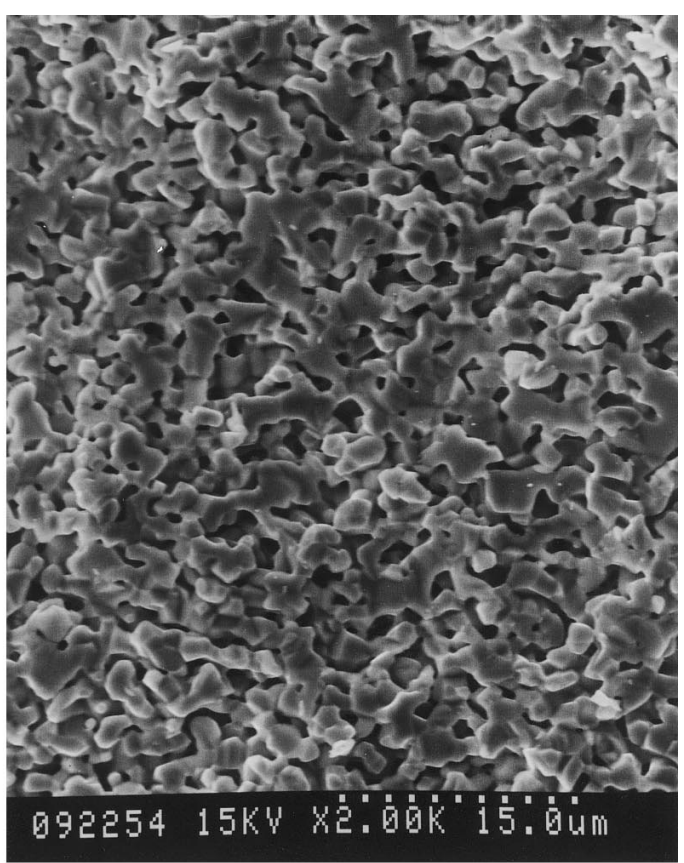

(b)

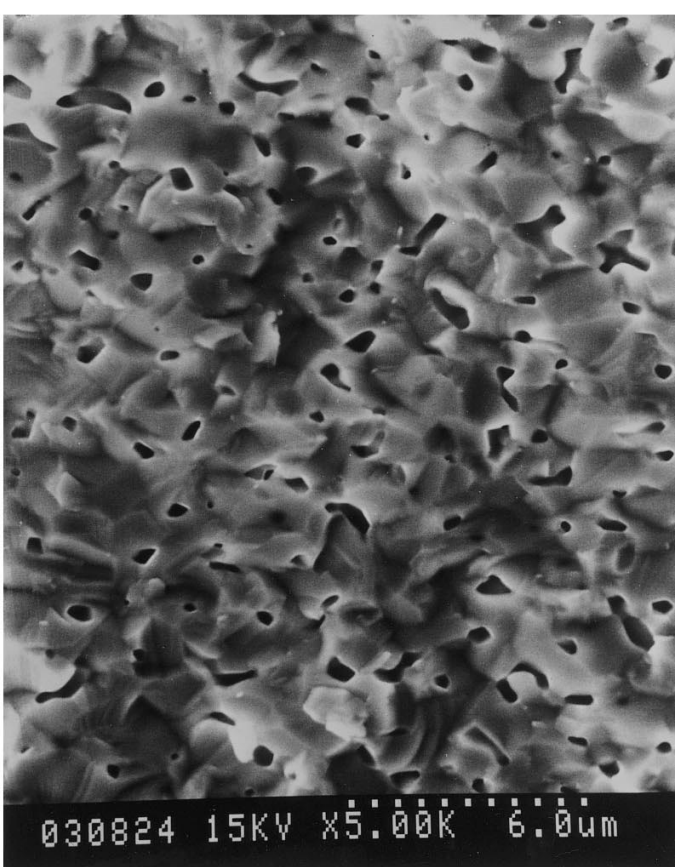

(d)

Fig. 12. SEM graphs of surface views (a, c) and fracture surfaces $(b, d)$ of sintered 20 YDC tapes from inferior starting powders: $(\mathrm{a}, \mathrm{b})$ as calcined powder, sintered at $1600^{\circ} \mathrm{C}$ for $2 \mathrm{~h}$; (c, d) wet milled powder, sintered at $1500^{\circ} \mathrm{C}$ for $2 \mathrm{~h}$.

For our routine casting experiments with doped ceria, a typical powder-to-binder and powder-toplasticizer ratio of 9 was employed.

\subsubsection{Sample flattening}

Samples from tapes cast under optimized conditions of slurry composition and viscosity were placed on a coarse YDC powder bed on alumina substrates, without a load, for sintering. The YDC powder bed prevented adhesion of the sticky films to the substrate, and diffusion of ceria from the bottom of the samples into the substrate at high temperatures $\left(\geq 1500^{\circ} \mathrm{C}\right) .{ }^{4}$ Slightly warped discs prepared in this way required an additional flattening step in order to use them for practical applications, e.g. electrochemical or mechanical testing. This could be carried out by refiring the sintered samples sandwiched in between flat alumina plates, under a heavy load of ca $50 \mathrm{~g} \mathrm{~cm}^{-2}$. An example of flat translucent samples obtained in 


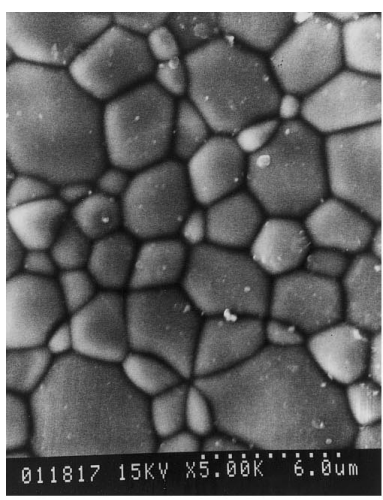

(a)

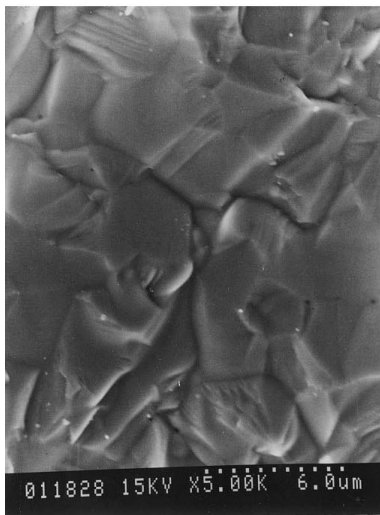

(b)

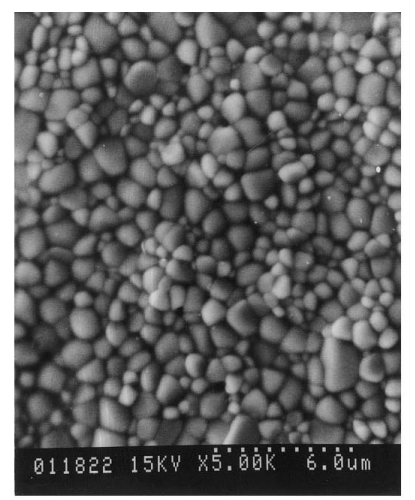

(c)

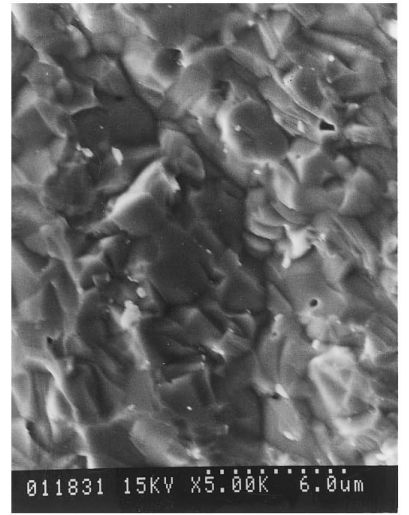

(d)

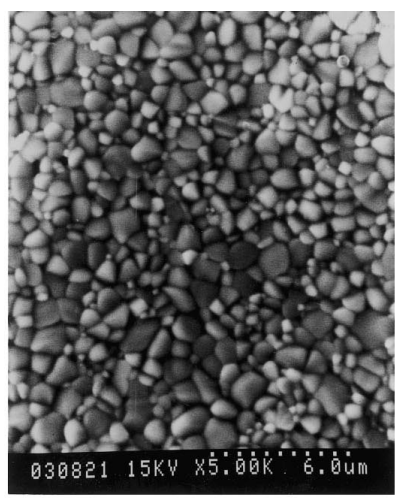

(e)

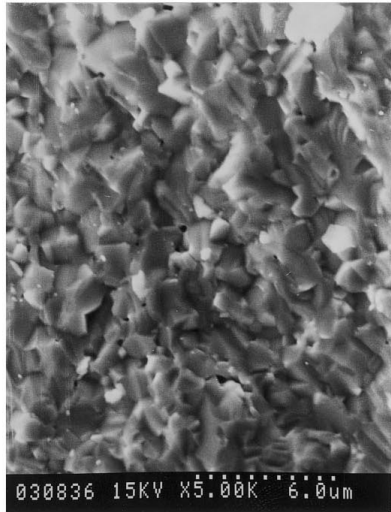

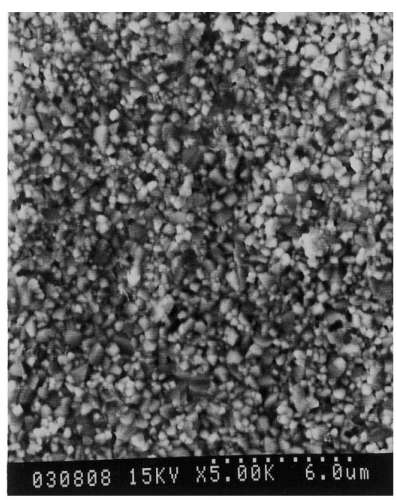

(g)

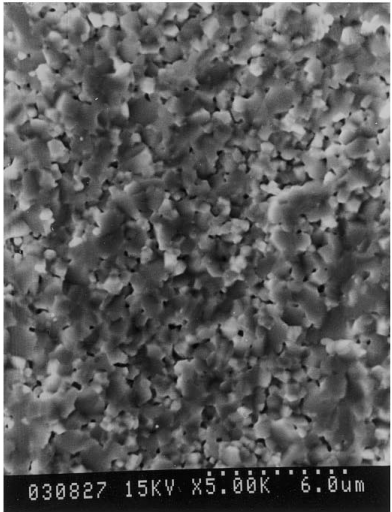

(h)

Fig. 13. SEM graphs of surface views (a, c, e, g) and fracture surfaces (b, d, f, h) of sintered 20 YDC tapes from dry milled starting powder: (a, b) sintered at $1600^{\circ} \mathrm{C}, 2 \mathrm{~h} ;(\mathrm{c}, \mathrm{d})$ sintered at $1500^{\circ} \mathrm{C}, 2 \mathrm{~h} ;(\mathrm{e}, \mathrm{f})$ sintered at $1400^{\circ} \mathrm{C}, 2 \mathrm{~h} ;(\mathrm{g}, \mathrm{h})$ sintered at $1300^{\circ} \mathrm{C}, 2 \mathrm{~h}$.

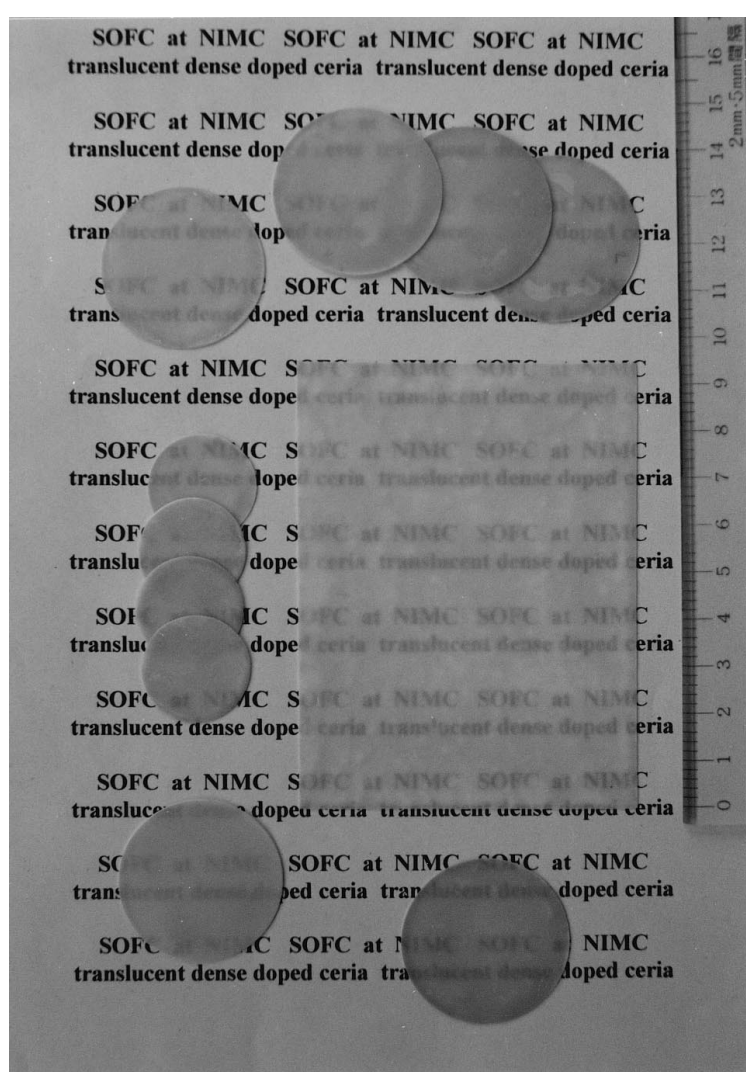

Fig. 14. Picture of flattened, densely sintered translucent 20 YDC samples $(0.15-0.25 \mathrm{~mm}$ thick). this way is presented in Fig. 14. The rectangular plate measures $9 \times 7 \times 0.016 \mathrm{~cm}$.

Owing to their high density and high homogeneity, both sintered compacts and tapes showed high conductivity of e.g. $0.06(\Omega \mathrm{cm})^{-1}$ at $750^{\circ} \mathrm{C}$ in air, which approaches that reported for pellets of more expensive Gd- and Sm-doped ceria, ${ }^{14,15}$ generally considered to be the best ceria-based conductors. Details on our conductivity data are published elsewhere. ${ }^{4}$

\section{SUMMARY}

Highly sinterable nano-sized yttria doped ceria powder was prepared by an optimized coprecipitation method. In addition to $\mathrm{pH}$ and solutions concentration control, alcohol washing of the precipitate and calcination at $700^{\circ} \mathrm{C}$ were identified as important factors in the overall preparation route. This powder could be formulated into tape cast slurries, cast to films and fired to high density at low temperature $\left(98 \%, 1400^{\circ} \mathrm{C}\right)$. Dry milling of the powder to reduce the average agglomerate size constituted the most important powder processing step. The surface area parameter was of minor 
importance. Slurry composition, casting viscosity, and firing cycles were optimized to deliver flat translucent samples showing very good conductivity behaviour. Given the low temperature densification of the films, cofiring with other materials (electrodes, composite electrolyte with YSZ) for SOFC application becomes feasible.

\section{ACKNOWLEDGEMENT}

J.V.H. is supported by the Science \& Technology Agency, Japan.

\section{REFERENCES}

1. VAN HERLE, J., HORITA, T., KAWADA, T., SAKAI, N., YOKOKAWA, H. \& DOKIYA, M., Preparation of doped ceria powder. In Proceedings of the 4th International Symposium on Solid Oxide Fuel Cells, ed. M. Dokiya, O. Yamamoto, H. Tagawa, \& S. C. Singhal. The Electrochemical Society Inc., Pennington, NJ, USA, pp. 1082-1092.

2. KLUG, H. P. \& ALEXANDER, L. E., X-Ray Diffraction Procedures, 2nd edn. John Wiley \& Sons, New York, 1974, pp. 625-628, 635, 656.

3. WEST, A. R., Solid State Chemistry and its Applications. John Wiley \& Sons, 1984, pp. 174-175.

4. VAN HERLE, J., HORITA, T., KAWADA, T., SAKAI, N., YOKOKAWA, H. \& DOKIYA, M., Sintering behaviour and ionic conductivity of yttria doped ceria. J. Eur. Ceram. Soc., in press.

5. DOKIYA, M., SAKAI, N., KAWADA, T., YOKOKAWA, H. \& ANZAI, I., Wet Process for Planar SOFC. In Proceedings of the 2nd International Symposium on Solid Oxide Fuel Cells, ed. F. Grosz, P. Zegers, S. C. Singhal \& O. Yamamoto. Commission of the European Community, Report EUR 13546 EN, 1991, pp. 127-134.

6. JORDAN, G. W. \& BÊRARD, M. F., Production of highly-sinterable rare earth oxide powders by controlled humidity dewatering of products. Ceram. Int., 9 (1983) 87-92.

7. DOLE, S. L., SCHEIDECKER, R. W., SCHIERS, L. E., BÊRARD, M. F. \& HUNTER, O., Technique for preparing highly-sinterable oxide powders.. Mater. Sci. Eng., 32 (1978) 277-281.

8. Gmelin's Handbook of Inorganic Chemistry, 8th edn. Part D5, S, Y, La-Lu Rare Earth Elements. Springer Verlag, Berlin, 1984, p. 136.

9. EL ADHAM, K. \& HAMMOU, A., Etude des propriótés électriques de solutions solides à base de dioxyde de cérium. J. Chim. Phys., 79 (1982) 633-644.

10. OVERS, A. \& RIESS, I., Properties of the solid electrolyte gadolinia doped ceria prepared by thermal decomposition of mixed cerium-gadolinium oxalate. J. Am. Ceram. Soc., 65 (1982) 606-609.

11. RIESS, I., BRAUNSHTEIN, D. \& TANNHAUSER, D. S., Density and ionic conductivity of sintered $\left(\mathrm{CeO}_{2}\right)_{0.82}\left(\mathrm{GdO}_{1.5}\right)_{0.18}$. J. Am. Ceram. Soc, 64 (1981) 479-845.

12. DURÁN, P., MOURÊ, C. \& JURADO, J. R., Sintering and microstructural development of ceria-gadolinia dispersed powders. J. Mater. Sci., 29 (1994) 1940-1948.

13. TOFT SØRENSEN, O., Udvikling og affrøvning af iltionledere til iltmåling i røggas, Risø Report M-2488, Research Centre Risø, Roskilde, Denmark, Feb. 1985, pp. 17-18.

14. EGUCHI, K., SETOGUCHI, T., INOUE, T. \& ARAI, H., Electrical properties of ceria-based oxides and their application to solid oxide fuel cells. Solid State Ionics, $\mathbf{5 2}$ (1992) 165-172.

15. INOUE, T., SETOGUCHI, T., EGUCHI, K. \& ARAI, H., Study of a solid oxide fuel cell with a ceria-based solid electrolyte. Solid State Ionics, 35 (1989) 285-291. 